\title{
Evaluating Emission Trading as a Policy Tool - Evidence from Conditional Jump Models
}

\author{
MARC GRONWALD \\ JANINA KETTERER
}

\author{
CESIFO WORKING PAPER NO. 2682 \\ CATEGORY 9: RESOURCE AND ENVIRONMENT ECONOMICS \\ JUNE 2009
}
An electronic version of the paper may be downloaded
- from the SSRN website:
- from the RePEc website:
- from the CESifo website:
www.SSRN.com
www.RePEc.org
www.CESifo-group.org/wp




\title{
Evaluating Emission Trading as a Policy Tool - Evidence from Conditional Jump Models
}

\begin{abstract}
This paper, first, empirically investigates European emission allowance (EUA) prices and, second, evaluates emission trading as a policy measure. Applying combined jump GARCH models yields strong evidence of conditional jump behavior. This implies that EUA prices are subject to unexpected movements and that a considerable degree of uncertainty is present. According to the real option literature, uncertainty has adverse effects on investment decisions. Thus, investments in abatement technologies are likely to be postponed due to the peculiar characteristics of emission allowance prices. Furthermore, this price behavior is at odds with the theoretical notion that emission prices equal marginal abatement costs.
\end{abstract}

JEL Code: C22, Q50.

Keywords: emission allowance prices, jumps, GARCH, real options.

Marc Gronwald

Ifo Institute for Economic Research at the

University of Munich

Poschingerstrasse 5

81679 Munich

Germany

gronwald@ifo.de
Janina Ketterer

Ifo Institute for Economic Research at the

University of Munich

Poschingerstrasse 5

81679 Munich

Germany

ketterer@ifo.de

June 2009 


\section{INTRODUCTION}

This paper's contribution to the literature is twofold. First, it empirically analyzes European emission certificate prices (EUA), using Chan and Maheu's (2002) auto-regressive jump-intensity (ARJI)-GARCH model. Second, the real options perspective allows to evaluate the empirical results on certificate prices and derive conclusions on emission trading as a policy tool.

Empirically analyzing emission allowance (EUA) prices receives growing attention in the literature. Several papers study the behavior of carbon prices and the development of the European carbon market. Most relevant results for this paper are from Daskalakis et al. (2009) who argue that the EUA future is characterized by jumps. Moreover, Paolella and Taschini (2008) as well as Benz and Trück (2009) find GARCH structure in the carbon price returns. However, jumps and conditional heteroscedasticity has not yet been treated in a single approach as brought forward in this paper. A combined approach is motivated by the particular strong influence of regulatory changes in carbon markets, such as decisions on the absolute supply, the allocation to different sectors or the manner of distribution. This particularity of carbon markets has been emphasized in a few recent papers, such as Yang et al. (2008) and Tuthill (2008). They conclude that regulatory decisions lead to jumps in the price data. In order to incorporate such discrete events, the empirical model allows for jumps as well as GARCH effects. Strong evidence of conditional jumps is found, which indicates that a considerable degree of uncertainty is present in the carbon market.

Given these results, policy implications are derived by assessing the effect of uncertainty from the real option perspective. This approach establishes an inverse relationship between uncertainty and investment, especially in the case of irreversible and industry-specific investments. According to Dixit and Pindyck (1994) a firm chooses to delay the expenditure with the prospect of gaining information on the profitability of a project. This insight can be applied to the specific situation of firms within the European Emission Trading Scheme (ETS). Here, firms face a fundamental decision - either they acquire sufficient certificates in the market or they reduce the carbon emissions they 
generate by investing in abatement technologies. Cleaner and more efficient production process save costs of future certificates and energy, but also represent irreversible expenditures. As the peculiar behavior of certificate prices introduces additional uncertainty, the real option literature predicts a delay of firm's abatement investment.

\section{MethoD}

Chan and Maheu's (2002) method extends traditional GARCH models by a conditional-jump component. This section briefly outlines this method. ${ }^{1}$

Consider the following model:

$$
y_{t}=\mu+\sum_{i=1}^{l} \phi_{i} y_{t-i}+\sqrt{h_{t}} z_{t}+\sum_{k=1}^{n_{t}} X_{t, k}
$$

with $z_{t} \sim N I D(0,1)$. $h_{t}$ is assumed to follow a $\operatorname{GARCH}(p, q)$ process [Bollerslev, 1986]:

$$
h_{t}=\omega+\sum_{i=1}^{q} \alpha_{i} \epsilon_{t-i}^{2}+\sum_{i=1}^{p} \beta_{i} h_{t-i}
$$

The conditional jump size $X_{t, k}$, given the history of observations $\Phi_{t-1}=$ $\left\{y_{t-1}, \ldots, y_{1}\right\}$, is assumed to be normally distributed with mean $\theta_{t}$ and variance $\delta_{t}^{2}: X_{t, k} \sim N\left(\theta_{t}, \delta_{t}^{2}\right)$. The number of jumps $n_{t}$ that arrive between $t-1$ and $t$ follows a Poisson distribution with $\lambda_{t}>0$ :

$$
P\left(n_{t}=j \mid \Phi_{t-i}\right)=\frac{\lambda_{t}^{j}}{j !} e^{-\lambda_{t}}
$$

where $\lambda_{t}$ measures the jump-intensity. Two variants of the model are considered here: a constant jump-intensity model with $\lambda_{t}=\lambda, \theta_{t}=\theta$, and $\delta_{t}^{2}=\delta^{2}$; and a time-varying jump-intensity model. For the case of the latter, $\lambda_{t}$ is assumed to follow the auto-regressive process

$$
\lambda_{t}=\lambda_{0}+\sum_{i=1}^{r} \rho_{i} \lambda_{t-i}+\sum_{i=1}^{s} \gamma_{i} \xi_{t-i}
$$

\footnotetext{
${ }^{1}$ For a more thorough discussion of the method the reader is referred to Chan and Maheu's (2002) original paper.
} 
This model class and bivariate extensions of which have been successfully applied to stock market returns [Chan and Maheu, 2002], exchange rates [Chan, 2003; Chan, 2004], and copper prices [Chan and Young, 2006]. The following section presents the results obtained from applying this method to emission allowance prices.

\section{Results}

The model is estimated for daily emission allowance spot prices $(24 / 06 / 2005$ - 29/12/2006) as well as 2008 future prices (22/04/2005 - 15/12/2008). Thus, both Phase I and early stage Phase II data is considered. First log-differences of the data is used and a constant as well as two lags of the spot price and one lag for the future price are included. ${ }^{2}$ Table 1 provides the estimation results. It is evident that for both price series all jump parameters are highly significant. What is more, Figure 1 vividly illustrates that the Chan and Maheu (2002) method is very well able to capture the emission allowance price's peculiar behavior. Displayed are the price together with the time-varying jump-intensities. It is evident that periods with larger price movements are accompanied by larger jump-intensities. In particular, the severe drop in the prices end of April 2006 is well captured by the model as indicated by the peak in the jump intensity (lower left panel). Prices dropped, when national emission reports confirmed a significant oversupply with certificates of most European installations. The estimates for the EUA future, furthermore, show that the jump behavior is also present in early Phase II stages, epitomized by the two jump intensity peaks January 2008 and October 2008. Possible sources for these sudden price movements that have been discussed in the literature include NAP announcements and relative changes in trading volumes [Sanin and Violante, 2009] as well as energy prices and unanticipated weather events [Alberola et al., 2008]. It is worth noting that the EUA price

\footnotetext{
${ }^{2}$ Spot price data from the environmental exchange Bluenext is used and available at www.bluenext.eu. Due to larger trading volumes, the data is preferred to spot price data from the EEX in Leipzig. The spot price sample end has been chosen because of the subsequent decrease of the price series to 0 , which can hardly be classified as representative price behavior. The future price data is obtained from the European Climate Exchange (www.ecx.eu).
} 
Table 1: Constant and Time-Varying Jump-Intensity Models

\begin{tabular}{c|c|c|c|c}
\hline \hline & \multicolumn{2}{|c|}{ Spot price } & \multicolumn{2}{c}{ Future price } \\
\hline Parameter & Constant & ARJI & Constant & ARJI \\
\hline \multirow{2}{*}{$\mu$} & $1.6 \mathrm{E}-03$ & 0.002 & $2.6 \mathrm{E}-03$ & $2.8 \mathrm{E}-03$ \\
& $(0.1170)$ & $(0.0331)$ & $(0.0028)$ & $(0.0003)$ \\
$\phi_{1}$ & 0.1652 & 0.1570 & 0.1049 & 0.0861 \\
& $(0.0063)$ & $(0.0109)$ & $(0.0044)$ & $(0.0273)$ \\
$\phi_{2}$ & -0.0872 & -0.1141 & - & - \\
& $(0.0960)$ & $(0.0340)$ & & \\
\hline$\omega$ & $5.8 \mathrm{E}-06$ & $8.9 \mathrm{E}-07$ & $1.8 \mathrm{E}-05$ & $1.6 \mathrm{E}-05$ \\
& $(0.4106)$ & $(0.2852)$ & $(0.0200)$ & $(0.0229)$ \\
$\alpha$ & 0.1453 & 0.0909 & 0.1086 & 0.0610 \\
& $(0.0043)$ & $(0.0010)$ & $(0.0002)$ & $(0.0237)$ \\
$\beta$ & 0.7444 & 0.7937 & 0.7902 & 0.8294 \\
& $(0.0001)$ & $(0.0001)$ & $(0.0001)$ & $(0.0001)$ \\
\hline \multirow{2}{*}{$\delta$} & 0.0419 & 0.0324 & 0.0334 & 0.0280 \\
& $(0.0001)$ & $(0.0001)$ & $(0.0001)$ & $(0.0001)$ \\
$\theta$ & -0.0170 & -0.0136 & $-9.7 \mathrm{E}-03$ & $-6.7 \mathrm{E}-03$ \\
& $(0.0125)$ & $(0.0043)$ & $(0.0468)$ & $(0.0355)$ \\
$\lambda$ & 0.2347 & 0.1725 & 0.2300 & 0.1113 \\
& $(0.0011)$ & $(0.0139)$ & $(0.0118)$ & $(0.0968)$ \\
$\rho$ & - & 0.6115 & - & 0.7560 \\
& & $(0.0001)$ & - & $(0.0118)$ \\
$\gamma$ & - & 1.120 & - & 0.5138 \\
& & $(0.0007)$ & & $(0.0174)$
\end{tabular}

Note: p-values in parentheses.

jump behavior is more pronounced than that of Dow Jones returns in Chan and Maheu's (2002) original application. While the height of peaks is similar in both studies, the frequency of peaks as well as the average jump intensity is higher for the EUA prices.

In a nutshell, strong evidence of conditional jumps is found in emission allowance prices, which indicates that the prices are subject to larger unexpected price movements. This, however, suggests that a considerable degree of uncertainty is present in the carbon market. The following section discusses the influence of this apparent uncertainty on the abatement strategy of complying firms. 
Figure 1: Emission Allowance Prices and Jump Intensity Intensities
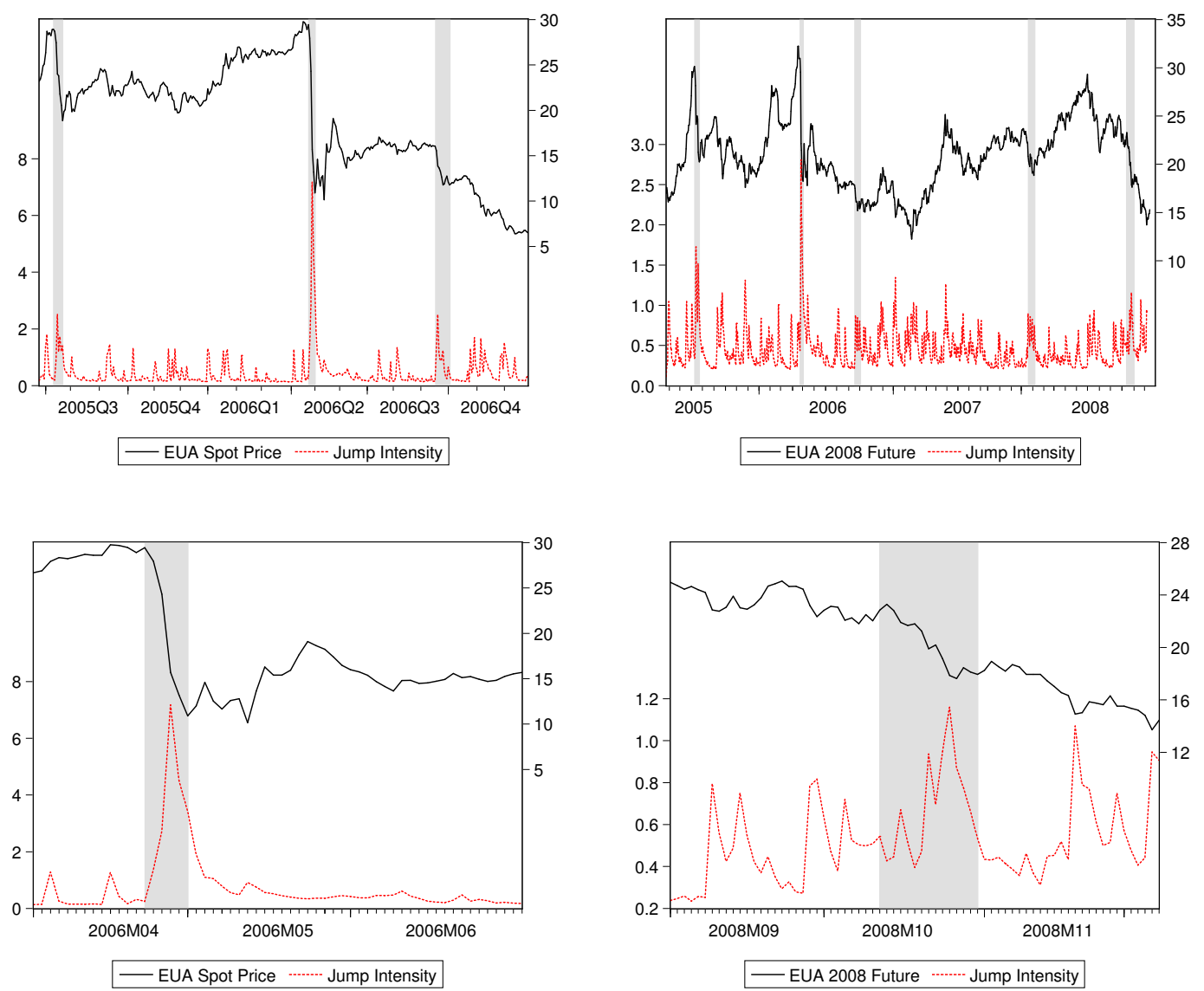

\section{Discussion}

The real option literature is most relevant as it investigates the effect of uncertainty on economic decision making [Dixit and Pindyck, 1994]. Concerning the decision making on the firm level, Bernanke (1983) as well as McDonald and Siegel (1986) point out that irreversible investments are more likely to be postponed if uncertainty on future returns arises. Dixit and Pindyck (1994) emphasize that in this situation the option to wait for additional information becomes more attractive. Uncertainty, for example arising from prices [Pindyck, 1981] or from future demand [Pindyck, 1993] makes future profits hard to calculate. Therefore, theory predicts a nega- 
tive relationship between the waiting option and an irreversible investment [Mohn and Misund, 2009]. ${ }^{3}$

The real options idea has not only been applied to investment decisions, but also plays an important role in environmental and resource economics. Arrow and Fisher (1974), Fisher (2000) and Pindyck (2000) model uncertainty originating from complex environmental interdependencies and discuss implications for policy decisions. As impact and costs of environmental degradation are hard to assess, the timing of environmental policies and related expenditures becomes more difficult. More recently Dangl and Wirl (2007) investigate how optimal intertemporal emission policies are affected by uncertainty about the temperature curve.

Particularly relevant are papers that apply the real option view to investment decisions under emission trading schemes. Herbelot (1994) and Isney (2003) both analyze the decision to retrofit a power plant under the Clean Air Act in the US, which bans $\mathrm{SO}_{2}$ emissions. What is more, some recent papers employ the real options approach to the ETS. In this specific context, firms face the decision whether to buy sufficient certificates or to reduce the carbon emissions they generate by investing in abatement technologies. Yang et al. (2008) as well as Tuthill (2008) frame a model on abatement decisions under the ETS. They find that the effect of regulatory uncertainty is particularly important within the European framework. By causing jumps in certificate prices, regulatory decisions add disturbance to the carbon market and consequently lead to a delay of investments.

Drawing from this theoretical literature, the evidence of jump behavior pose an additional source of uncertainty in investment decisions, as they make calculation of compliance costs more difficult. Facing this uncertainty, firms become more hesitant about investments and emission-reducing retrofits will be realized later in time.

\footnotetext{
${ }^{3}$ This conclusion has not been undisputed. Hartman (1972), later extended by Abel (1983) analyze a setting where uncertainty will have an positive or at least ambiguous effect on investment. As a result, this controversy has been investigated in a large number of empirical studies. The results have been surveyed by Carruth (2000). Overall, a negative relationship between uncertainty and investment is confirmed that probably dominates positive effects.
} 
Evidence of jumps is found throughout the estimation period, whereas the intensity of jumps changes substantially over time. As jumps can be found throughout the sample, a considerable degree of uncertainty seems to be inherent in the system. Amongst the influencing factors are fossil fuel prices, weather events and the market power of large firms. Moreover, some extraordinarily high jumps can be ascribed to decisions on provision and allocation of certificates. The event in April 2006 exemplifies how uncertainty is introduced by the regulatory framework. Such influence of regulatory decisions on price behavior has been presumed by Tuthill (2008) as well as Sanin and Violante (2009). Certainly, Phase I was created as test period, introducing regulators as well as firms to the newly installed mechanism. However, the delayed submission of National Allocation Plans for Phase II again created insecurity about the final issuance of all Member States. Further possible sources of disturbance result from the national limits on CDM and JI credits which can be used for compliance within the ETS. The impact of increased auctioning, finally, remains equally unclear. Hence, if regulators do not learn from the Phase I events and improve the system, price uncertainty will remain problematic in the future.

This paper aims to evaluate emission trading and its performance with regard to the reduction of carbon emissions. Evidence is found that investments might be postponed under the ETS. According to Sinn (2008), later abatement of carbon emissions leads to higher atmospheric carbon concentration which accelerates climate change. What is more, the sensitivity of EUA prices to various sources suggests that they do not reflect marginal abatement costs. Therefore, concerns recently expressed by Hintermann (2009) are

reinforced. These effects are often neglected when assessing emission trading against other environmental policies.

\section{ACKNOWLEDGEMENTS}

The authors gratefully acknowledge valuable comments by Klaus Wohlrabe, Markus Zimmer, Beat Hintermann as well as CMS 2009 participants. 


\section{REFERENCES}

Abel, A.B. (1983). "Optimal Investment under Uncertainty", American Economic Review 73: 228-233

Alberola, E., J. Chevallier and B. Cheze (2008). "Price Drivers and Structural Breaks in European Carbon Prices 20052007", Energy Policy 36: 787-797

ARrow, H.J. AND A.C. Fisher (1974). "Environmental preservation, Uncertainty, and Irreversibility", Quaterly Journal of Economics 88: 312-319

Benz, E. And S. Trück (2009). "Modeling the Price Dynamics of $\mathrm{CO}_{2}$ Emission Allowances", Energy Economics 31: 4-15

Bernanke, B.S. (1983). "Irreversibility, Uncertainty, and Cyclical Investment", Quarterly Journal of Economics: 85-106

Bollerslev, T. (1986). "Generalized Autoregressive Conditional Heteroskedasticity", Journal of Econometrics 31: 309-328

Carruth, A., A. Dickerson and A. Henley (2000). "What Do We Know About Investment under Uncertainty", Journal of Economic Surveys 14: 119-153

Chan, W.H. (2003). "A Correlated Bivariate Poisson Jump Model for Foreign Exchange", Empirical Economics 28: 669-689

Chan, W.H. (2004). "Conditional Correlated Jump Dynamics in Foreign Exchange", Economics Letters 83: 23-28

Chan, W.H. and J.M. Maheu (2002). "Conditional Jump Dynamics in Stock Market Returns", Journal of Business \& Economic Statistics 20: 377-389

Chan, W.H. And D. Young (2006). "Jumping Hedges: an Examination of Movements in Copper Spot and Futures Markets", Journal of Futures Markets 26: 169188

Dangl, T. And F. Wirl (2007). "The Consequences of Irreversibility on Optimal Intertemporal Emission Policies under Uncertainty", Central European Journal of Operations Research 15: 143-166

Daskalaiks, G., D. Psychoyios and R.N. Markellos (2009). "Modeling $\mathrm{CO}_{2}$ Emission Allowance Prices and Derivatives: Evidence from the European Trading Scheme", Journal of Banking \& Finance forthcoming

Dixit, A.K. And R.S. Pindyck (1994). "Investment under Uncertainty", Princeton University Press, Princeton

Fisher, A.C. (2000). "Investment under Uncertainty and Option Value in Environmental Economics", Resource and Energy Economics 22: 197-204 
Hartman, R. (1972). "The Effects of Price and Cost Uncertainty", Journal of Ecnomic Theory 5: 258-266

Herbelot, O. (1992). "Option Valuation of Flexible Investments: the Case of Environmental Investments in the Electric Power Industry", unpublished Ph.D. thesis Massachusetts Institute of Technology

Hintermann, B. (2009). "An Option Pricing Approach to CO2 Allowances in the EU ETS", mimeo ETH Zurich

InSLEY, M.C. (2003). "On the Option to Invest in pollution Control under a Regime of Tradable Emissions Allowances", Canadian Journal of Economics 36: 860-883

Mc Donald, R. And D. Siegel (1986). 'The Value of Waitung to Invest”, The Quaterly Journal of Economics November: 707-727

Mohn, K. And B. Misund (2009). 'Investment and Uncertainty in the International Oil and Gas Industry", Energy Economics 31: 240-248

Paolella, M. and L. Taschini (2008). "An Econometric Analysis of Emission Trading Allowances", Journal of Banking and Finance 32: 2022-2032

PINDYCK, R.S. (1981). "The Optimal Production of an Exhaustible Resource when Price is Exogenous and Stochastic", Scandinavian Journal of Economics 83: 277288

PInDyCK, R.S. (1993). "A Note on Competitive Investment under Uncertainty", American Economic Review 83: 273-277

PInDyCK, R.S. (2000). "Irreversibilities and the Timing of Environmental Policy", Resource and Energy Economics 22: 233-259

PINDyCK, R.S. (2002). "Optimal Timing Problems in Environmental Economics", Journal of Economic Dynamics and Control 26: 1677-1697

Sanin, M.E. And F. Violante. (2009). "Understanding Volatility Dynamics in the EU-ETS Market: Lessons from the Future", CORE Discussion Paper 2009/24

Sinn, H.W. (2008). "Public Policies against Global Warming: a Supply Side Approach", International Tax and Public Finance 15: 360-394

Tuthill, L. (2008). "Investment in Electricity Generation under Emission Price Uncertainty: the Plant-Type Decision", Oxford Institute for Energy Studies Working Paper EV 39

Yang, M., W. Blyth, R. Bradley, D. Bunn, C. Clarke and T. Wilson (2008). "Evaluating the Power Investment Options with Uncertainty in Climate Policy", Energy Economics 30: 1933-1950 


\section{CESifo Working Paper Series}

for full list see www.cesifo-group.org/wp

(address: Poschingerstr. 5, 81679 Munich, Germany, office@cesifo.de)

2621 Yin-Wong Cheung and Xingwang Qian, The Empirics of China's Outward Direct Investment, April 2009

2622 Frédérique Bec and Christian Gollier, Assets Returns Volatility and Investment Horizon: The French Case, April 2009

2623 Ronnie Schöb and Marcel Thum, Asymmetric Information Renders Minimum Wages Less Harmful, April 2009

2624 Martin Ruf and Alfons J. Weichenrieder, The Taxation of Passive Foreign Investment Lessons from German Experience, April 2009

2625 Yao Li, Borders and Distance in Knowledge Spillovers: Dying over Time or Dying with Age? - Evidence from Patent Citations, April 2009

2626 Jim Malley and Ulrich Woitek, Technology Shocks and Aggregate Fluctuations in an Estimated Hybrid RBC Model, April 2009

2627 Jin Cao and Gerhard Illing, Endogenous Systemic Liquidity Risk, April 2009

2628 Thiess Buettner and Bjoern Kauder, Revenue Forecasting Practices: Differences across Countries and Consequences for Forecasting Performance, April 2009

2629 Håkan Selin, The Rise in Female Employment and the Role of Tax Incentives - An Empirical Analysis of the Swedish Individual Tax Reform of 1971, April 2009

2630 Nick Johnstone and Ivan Hascic, Environmental Policy Design and the Fragmentation of International Markets for Innovation, April 2009

2631 Spiros Bougheas, Richard Kneller and Raymond Riezman, Optimal Education Policies and Comparative Advantage, April 2009

2632 Jay Pil Choi and Heiko Gerlach, Multi-Market Collusion with Demand Linkages and Antitrust Enforcement, April 2009

2633 Thor O. Thoresen, Income Mobility of Owners of Small Businesses when Boundaries between Occupations are Vague, April 2009

2634 Guido Schwerdt and Amelie C. Wuppermann, Is Traditional Teaching really all that Bad? A Within-Student Between-Subject Approach, April 2009

2635 Kurt R. Brekke, Luigi Siciliani and Odd Rune Straume, Hospital Competition and Quality with Regulated Prices, April 2009

2636 Peter Diamond, Taxes and Pensions, April 2009 
2637 Shoshana Grossbard, How "Chicagoan” are Gary Becker's Economic Models of Marriage?, May 2009

2638 Roland Strausz, Regulatory Risk under Optimal Incentive Regulation, May 2009

2639 Holger Zemanek, Ansgar Belke and Gunther Schnabl, Current Account Imbalances and Structural Adjustment in the Euro Area: How to Rebalance Competitiveness, May 2009

2640 Harald Hau and Marcel Thum, Subprime Crisis and Board (In-)Competence: Private vs. Public Banks in Germany, May 2009

2641 Martin Halla, Mario Lackner and Friedrich G. Schneider, An Empirical Analysis of the Dynamics of the Welfare State: The Case of Benefit Morale, May 2009

2642 Balázs Égert, Infrastructure Investment in Network Industries: The Role of Incentive Regulation and Regulatory Independence, May 2009

2643 Christian Gollier, Expected Net Present Value, Expected Net Future Value, and the Ramsey Rule, May 2009

2644 Sören Blomquist and Håkan Selin, Hourly Wage Rate and Taxable Labor Income Responsiveness to Changes in Marginal Tax Rates, May 2009

2645 Dominique Demougin, Oliver Fabel and Christian Thomann, Implicit vs. Explicit Incentives: Theory and a Case Study, May 2009

2646 Francesco C. Billari and Vincenzo Galasso, What Explains Fertility? Evidence from Italian Pension Reforms, May 2009

2647 Kjell Arne Brekke, Karen Evelyn Hauge, Jo Thori Lind and Karine Nyborg, Playing with the Good Guys - A Public Good Game with Endogenous Group Formation, May 2009

2648 Guglielmo Maria Caporale and Luis A. Gil-Alana, Multi-Factor Gegenbauer Processes and European Inflation Rates, May 2009

2649 Henning Bohn, A Static Model for Voting on Social Security, May 2009

2650 Markus Haavio and Kaisa Kotakorpi, The Political Economy of Sin Taxes, May 2009

2651 Augusto de la Torre, María Soledad Martínez Pería and Sergio L. Schmukler, Drivers and Obstacles to Banking SMEs: The Role of Competition and the Institutional Framework, May 2009

2652 Tobias Lindhe and Jan Södersten, Dividend Taxation, Share Repurchases and the Equity Trap, May 2009

2653 Assaf Razin and Edith Sand, Migration-Regime Liberalization and Social Security: Political-Economy Effect, May 2009 
2654 Yin-Wong Cheung and Hiro Ito, A Cross-Country Empirical Analysis of International Reserves, May 2009

2655 Bart Cockx and Bruno Van der Linden, Flexicurity in Belgium. A Proposal Based on Economic Principles, May 2009

2656 Michael Melvin, Lukas Menkhoff and Maik Schmeling, Exchange Rate Management in Emerging Markets: Intervention via an Electronic Limit Order Book, May 2009

2657 Susanne Neckermann, Reto Cueni and Bruno S. Frey, What is an Award Worth? An Econometric Assessment of the Impact of Awards on Employee Performance, May 2009

2658 Steven Brakman, Harry Garretsen and Charles van Marrewijk, Economic Geography within and between European Nations: The Role of Market Potential and Density across Space and Time, May 2009

2659 Giovanni Facchini and Cecilia Testa, Reforming Legislatures: Is one House better than two?, May 2009

2660 Carsten Kowalczyk and Raymond Riezman, Trade Agreements, May 2009

2661 Oliver Falck, Stephan Heblich and Elke Luedemann, Identity and Entrepreneurship, May 2009

2662 Christian Lessmann and Gunther Markwardt, One Size Fits All? Decentralization, Corruption, and the Monitoring of Bureaucrats, May 2009

2663 Felix Bierbrauer, On the Legitimacy of Coercion for the Financing of Public Goods, May 2009

2664 Alessandro Cigno, Agency in Family Policy: A Survey, May 2009

2665 Claudia M. Buch and Christian Pierdzioch, Low Skill but High Volatility?, May 2009

2666 Hendrik Jürges, Kerstin Schneider, Martin Senkbeil and Claus H. Carstensen, Assessment Drives Learning: The Effect of Central Exit Exams on Curricular Knowledge and Mathematical Literacy, June 2009

2667 Eric A. Hanushek and Ludger Woessmann, Schooling, Cognitive Skills, and the Latin American Growth Puzzle, June 2009

2668 Ourania Karakosta, Christos Kotsogiannis and Miguel-Angel Lopez-Garcia, Does Indirect Tax Harmonization Deliver Pareto Improvements in the Presence of Global Public Goods?, June 2009

2669 Aleksandra Riedl and Silvia Rocha-Akis, Testing the Tax Competition Theory: How Elastic are National Tax Bases in OECD Countries?, June 2009 
2670 Dominique Demougin and Carsten Helm, Incentive Contracts and Efficient Unemployment Benefits, June 2009

2671 Guglielmo Maria Caporale and Luis A. Gil-Alana, Long Memory in US Real Output per Capita, June 2009

2672 Jim Malley and Ulrich Woitek, Productivity Shocks and Aggregate Cycles in an Estimated Endogenous Growth Model, June 2009

2673 Vivek Ghosal, Business Strategy and Firm Reorganization under Changing Market Conditions, June 2009

2674 Francesco Menoncin and Paolo M. Panteghini, Retrospective Capital Gains Taxation in the Real World, June 2009

2675 Thomas Hemmelgarn and Gaëtan Nicodème, Tax Co-ordination in Europe: Assessing the First Years of the EU-Savings Taxation Directive, June 2009

2676 Oliver Himmler, The Effects of School Competition on Academic Achievement and Grading Standards, June 2009

2677 Rolf Golombek and Michael Hoel, International Cooperation on Climate-Friendly Technologies, June 2009

2678 Martin Cave and Matthew Corkery, Regulation and Barriers to Trade in Telecommunications Services in the European Union, June 2009

2679 Costas Arkolakis, A Unified Theory of Firm Selection and Growth, June 2009

2680 Michelle R. Garfinkel, Stergios Skaperdas and Constantinos Syropoulos, International Trade and Transnational Insecurity: How Comparative Advantage and Power are Jointly Determined, June 2009

2681 Marcelo Resende, Capital Structure and Regulation in U.S. Local Telephony: An Exploratory Econometric Study; June 2009

2682 Marc Gronwald and Janina Ketterer, Evaluating Emission Trading as a Policy Tool Evidence from Conditional Jump Models, June 2009 